A autoraresponde

\section{Theauthor replies}

Ao retomar a palavra, depois de ler o que escreveram os colegas a partir do artigo de debate, gostaria de assinalar como um dos pontos comuns mais relevantes que todos os quatro assinalaram a importância do que a área conseguiu até aqui, como patamar para dar passos seguros rumo a novos desafios.

Feita essa breve consideração, inicio o diálogo com o texto de Rita Barata e Ricardo Ventura. Esses dois autores, nossos atuais representantes na CAPES, reafirmam e reforçam tudo o que foi colocado sobre a área. De um lado, o vigor, o crescimento e o contínuo aumento de qualidade e da competitividade; de outro, alguns problemas reincidentes como as desigualdades regionais e entre os cursos, e os desafios de se realizar uma avaliação de mérito que também leve em conta as peculiaridades institucionais e regionais dos programas. $M$ as os autores vão além: valorizam, a meu ver, corretamente, o processo de avaliação da CAPES com tudo quanto ele traz de padronização, de orientação para os coordenadores ede consequências práticas. Concordo com Rita e Ricardo, pois considero o processo de avaliação daCAPES, um bem do sistema deciência e tecnologia do país, na medida em que atua visando a tornar as pós-graduações eficientes na formação de educadores e pesquisadores de elevado nível. Segundo esses autores, nossos bons programas se equi param hojeaos internacionais. Eles também deixam claro que, enquanto representantes, estão investindo em valorizar e aperfeiçoar, dentro de um complexo sistema deavaliação padronizado, o reconhecimento da especificidade, da riqueza e do comprometimento de nossa área com sua história e com o SUS. No entanto, como também referem, a avaliação da CAPES é apenas um instrumento de promoção da qualidade educacional do país. Cabe a insti- tuições como aABRASCO investir em iniciativas tais como o Fórum de Coordenadores e processos avaliativos próprios, levando a área a se perguntar sobre questões que não constituem nem interesse especifico enem alcance da CAPES. $\mathrm{Ou}$ seja, não podemos esperar da CAPES o que ela não pode oferecer.

A seguir, interajo com o provocador texto de Carvalheiro, "Janus bifronte", em que o autor, com uma beleza de estilo ímpar e com a argúcia de quem tem muita experiência, história, entendimento e compromisso, ao mesmo tempo valoriza e critica 0 alcance de nossas reflexões e ações: a ciência já feita, a ciência oficial que vem dos relatórios da CAPES e a ciência pulsante e presente, com toda a sua potência transformadora, bebendo na fonte originária do campo da Saúde Coletiva. A meu ver, o que faltou ao meu texto, Carvalheiro completou, entrando no mé rito de um passado rico e cheio de história e militância e nas perspectivas de futuro. Eu diria, dialogando com ele, queouvir o estabelecido aqui foi necessário e, acredito, importante, para acompanhar a memória do que vem sendo construído como missão da ABRASCO e, também, para alertar sobre as várias possibilidades e rumos de quem só pode ousar quando tem um plano de vôo e conhece tanto o céu como o lugar do pouso provisório. 0 sistema de avaliação da CAPES, por mais oficial que seja e por mais tensão que gere, possui meios de atingir o mais possível a realidade dos programas e, se assim não fosse, perderia sua credibilidade. Nossa pesquisa baseou-se nos dados da CAPES, mas também foi a campo e buscou, sobretudo, aqueles que são os verdadeiros produtos de nossa ação, os egressos. No entanto, concordo com Carvalheiro que muita coisa nos espera nesse pensar e por fazer, tanto no que se refere ao avanço científico da área como no seu irrestrito compromisso com a construção do SUS.

Pedindo licença a Carvalheiro para estender o sentido do mito narrado primeiro por Latour e depois por ele, continuarei usando a metáfora das duas frontes de Janus, mas noutro sentido. Ou seja, não para falar do contraste entre estabelecido e o pulsante, como já citado, mas para tratar da dupla cara da pós-graduação em Saúde Coletiva: comprometida e crescentemente competentena formação de alto nível e na produção científica e, ao mesmo tempo, buscando engajar-se no aprofundamento e intensificação da produção tecnológica e da inovação peculiares a nossa área. N esse sentido, introduzo a fala de Reinaldo Guimarães que, apoiado nos documen- 
tos oficiais sobre o tema, aponta para a urgente necessidade de pensarmos a aplicação prática e imediata dos conhecimentos gerados no nosso campo: de que ao mérito científico sejam agregados componentes de prioridade, definidos por atores de dentro e, principalmente, de fora da comunidade científica; ênfase no componente tecnológico e na busca da inovação, deslocando o tradicional balanço observado na pesquisa realizada em nosso país; e reforço do componente empresarial, contem plando associações de em presas com grupos e instituições de pesquisa e, também, estimulando diretamente 0 desenvolvimento e a inovação nas empresas, diz 0 autor. Reinaldo, colega nosso que também é Secretário de Ciência e Tecnologia do M inistério da Saúde e tem sido um arauto da importância de um órgão que trate da estreita relação entre pesquisas em saúde e desenvolvimento tecnológico, completa seu pensamento dizendo: "a área de Saúde Coletiva parece preparada para entrar sem medo no crescimento da investigação que associa o avanço do conheci- mento a considerações de utilização precoce dos resultados desse avanço" em que a contribuição de atores de fora do mundo da ciência é bastante comum e crescentemente relevante. Dialogando com ele, eu diria que faz muito tempo que saímos da resistência e colocamos nossa cara a tapa. M as e óbvio que nos falta muito para realizar uma adequação de nossas teorias e práticas às necessidades da saúde do povo brasileiro.

Termino este debate, como deve ser todo bom debate, levantando questões para o próximo passo: (1) a necessidade de aprofundar o tema da re levância social da pós-graduação para o SUS, tema que não foi suficientemente tratado no estudo atual; (2) a inflexão sobre como estreitar os laços entre produção científica e produção tecnológica; (3) o aprofundamento sobre formação e mercado de trabalho para os profissionais de saúde; (5) a maior articulação esolidariedadeentreprogramas mais fortes e mais fracos; sem nunca esquecer que o preço da vitória cobra a eterna vigilância quanto à qualidade de nossa pós-graduação. 